\title{
Phosphorus forms and lability of organic matter during anaerobic digestion of swine manure
}

\section{Formas de fósforo e labilidade da matéria orgânica durante a biodegradação anaeróbia do dejeto suíno}

\author{
José de Souza Oliveira Filho'; Thales Vinicius de Araújo Viana²; Benito Moreira de \\ Azevedo $^{2}$; Geocleber Gomes de Sousa ${ }^{3}$; Marcos Gervasio Pereira ${ }^{4 *}$
}

\begin{abstract}
Understanding the dynamics of the organic matter and nutrients in pig manure submitted to anaerobic digestion is important to assist in decision-making regarding the use of anaerobic biofertilizer in agriculture. Accordingly, this study was carried out with the objective of evaluating the changes in organic matter, quantified as the content of carbon in the humic and oxidizable fractions, and in the content of the organic and inorganic forms of phosphorus in the solid fraction of the manure, as a function of digestion time in anaerobic reactors. Evaluations were carried out after 7, 14, 21, 28, 35, 42, and 49 days of digestion, and the results were compared to the raw manure. Changes in organic matter occurred mostly in the labile fractions (fulvic acid and the F1 fraction), the content of which underwent a reduction, favoring the accumulation of more recalcitrant fractions in the final biofertilizer (humic acid and the F2, F3, and F4 fractions). Total P content did not change throughout the digestion process. However, the size of inorganic fraction of water-extractable P decreased by $16.7 \%$ after 49 days of digestion, as it was consumed by the decomposing microbiota to form stabilized organic matter, which accumulated along with the more recalcitrant fractions of $\mathrm{P}$ in the final biofertilizer. Therefore, the use of swine manure-derived anaerobic biofertilizer has less risk of environmental contamination with excessive $\mathrm{P}$ than the direct application of raw manure to the soil.
\end{abstract}

Key words: Organic fertilizer. Bioavailability of nutrients. Biogas.

\section{Resumo}

O entendimento da dinâmica da matéria orgânica e dos nutrientes no dejeto suíno submetido à biodegradação anaeróbia é importante por auxiliar nas tomadas de decisão para a utilização do biofertilizante anaeróbio como fertilizante agrícola. Nesse sentido, desenvolveu-se um estudo, utilizando reatores anaeróbios de bancada, com o objetivo de avaliar as mudanças na matéria orgânica, através da quantificação do carbono nas frações húmicas e oxidáveis, e nas formas orgânicas e inorgânicas de fósforo da fração sólida do dejeto suíno, em função do tempo de biodegradação. Realizaram-se avaliações nos seguintes tempos de retenção hidráulica: 7, 14, 21, 28, 35, 42 e 49 dias de biodegradação e os resultados comparados com o dejeto não degradado. As mudanças na matéria orgânica ocorreram

\footnotetext{
${ }^{1}$ Prof. Dr., Universidade Federal do Ceará, UFC, Departamento de Ciências do Solo, Fortaleza, CE, Brasil. E-mail: jfilhomesti@ gmail.com

2 Profs. Drs., UFC, Departamento de Engenharia Agrícola, Fortaleza, CE, Brasil. E-mail: thales@ufc.br; benito@ufc.br

3 Prof. Dr., Universidade da Integração Internacional da Lusofonia Afro-Brasileira, UNILAB, Instituto de Desenvolvimento Rural, Redenção, CE, Brasil. E-mail: sousasolosgeo@hotmail.com

4 Prof. Dr., Universidade Federal Rural do Rio de Janeiro, UFRRJ, Departamento de Solos, Seropédica, RJ, Brasil. E-mail: mgervasiopereira@gmail.com

* Author for correspondence
} 
em suas frações mais lábeis (C-ácido fúlvico e fração F1) com redução dos seus conteúdos, favorecendo o acúmulo de frações mais recalcitrantes no biofertilizante final (C-ácido húmico e frações F2, F3 e F4). $\mathrm{O}$ conteúdo total de $\mathrm{P}$ não sofreu mudanças ao longo do processo. No entanto, a fração inorgânica de $\mathrm{P}$ extraível em água reduziu em 16,7 \% após 49 dias de biodegradação, sendo consumida pela microbiota decompositora para a formação de matéria orgânica estabilizada, que se acumula, juntamente com as frações mais recalcitrantes de $\mathrm{P}$ no biofertilizante final. $\mathrm{O}$ uso do biofertilizante anaeróbio suíno possui, portanto, menor risco de contaminação ambiental pelo excesso de $\mathrm{P}$ do que a aplicação direta do dejeto in natura no solo.

Palavras-chave: Fertilizante orgânico. Biodisponibilidade de nutrientes. Biogas.

\section{Introduction}

Livestock plays an important economic and social role throughout the world, being responsible for a significant portion of the global food production that seeks to guarantee food security to the human population. As a consequence of the intensification of activities linked to this sector, livestock production began to contribute significantly to global emissions of greenhouse gases, and has become an active agent involved in global climate change.

In the context of the potential environmental impacts of the various activities related to animal production, pig breeding stands out due to the large volume of manure generated in a relatively small production space therein. Taking into account the release of the gases $\mathrm{CO}_{2}, \mathrm{CH}_{4}$, and $\mathrm{N}_{2} \mathrm{O}$, it has been estimated that this activity has the potential to emit around $448 \mathrm{~kg}$ of $\mathrm{CO}_{2}$ equivalents into the atmosphere per pig produced, or $4.9 \mathrm{~kg}$ of $\mathrm{CO}_{2}$ equivalents per $\mathrm{kg}$ of carcass produced (PHILIPPE; NICKS, 2015).

As a strategy to reduce the environmental impact of the large volume of manure produced by pig farming, anaerobic digestion has been used. Anaerobic digestion consists of the transformation of organic matter of the manure under anaerobic conditions into biogas $\left(\mathrm{CH}_{4}\right.$ and $\left.\mathrm{CO}_{2}\right)$, which can be used as a source of renewable energy. This process also produces a residue at the end of the process (biofertilizer) containing high concentrations of nitrogen $(\mathrm{N})$ and phosphorus $(\mathrm{P})$, which has often been used in agriculture as a source of plant nutrients.

In the long term, if biogas is used as a means for the sustainable production of renewable energy, there will be a strong increase in the demand for this source of energy. This will increase the volume of biofertilizer generated, which will then need to have a proper final destination. The correct destination of the biofertilizer in agricultural use must take into account the support capacity of the soil (SZOGI et al., 2015), as well as aspects of the chemical nature of the biofertilizer, such as its elemental composition (MOLLER; MULLER, 2012), the presence of contaminants in it (FONGARO et al., 2017; RODRIGUEZ-NAVAS et al., 2013), and the dynamics of nutrients during the digestion process, as all of these will affect the agronomic potential of the final product generated.

The application of anaerobic biofertilizers in agriculture to meet the $\mathrm{N}$ needs of crops leads, in most cases, to an excessive addition of $\mathrm{P}$ to the soil, causing an imbalance in the supplies of these nutrients in the soil (GARCIA-ALBACETE et al., 2012). There is also the possibility of the excess supply of $\mathrm{P}$ causing environmental contamination leading to the eutrophication of water courses. In this case, greater attention should be paid to $\mathrm{P}$ fractions with greater lability and mobility in the soil, such as those associated with water-soluble inorganic phosphates, due to them having the greatest potential for causing environmental contamination (LI et al., 2014; TIECHER et al., 2014; TORRI et al., 2017).

During the digestion process, the consumption of sugars, proteins, amino acids, and volatile fatty acids, which are used by microorganisms as sources of carbon (C), occurs, reducing the content of the more labile fractions of organic matter $(\mathrm{OM})$ in the biofertilizer and promoting the accumulation of more recalcitrant forms of OM (TAMBONE 
et al., 2013). However, according to Provenzano et al. (2014), labile forms of $\mathrm{C}$, such as those associated with the fulvic acid fraction, can remain in the biofertilizer, serving as a labile $\mathrm{C}$ source for soil microorganisms after the application of the biofertilizer in agricultural areas.

Considering that approximately $40 \%$ of the total content of $\mathrm{P}$ in manure is in organic forms (LI et al., 2014), it is likely that the chemical changes that occur in the organic matrix of the manure during the digestion process, followed by the mineralization of organic $\mathrm{P}(\mathrm{Po})$ in the matrix (GUNGOR; KARTHIKEYAN, 2008), increase the relative content of $\mathrm{P}$ fractions with greater lability out of the total content of this nutrient in the biofertilizer. The increased content of the most labile $\mathrm{P}$ fractions means that a portion of this nutrient in the biofertilizer is already readily available for use by plants. However, this may also induce an increased risk of environmental contamination through the leaching of phosphate ions into groundwater (SONG et al., 2017).

The objective of this study was to assess the chemical changes in the $\mathrm{OM}$ in pig manure by quantifying the $\mathrm{C}$ content in the humic and oxidizable fractions, as well as the changes to the bioavailability of $\mathrm{P}$ in terms of its relative content in the organic and inorganic fractions, during the anaerobic digestion process. Accordingly, the following hypotheses were tested: i) during anaerobic digestion, the consumption of the OM fractions with greater lability and an increase in the content of more bioavailable forms of $\mathrm{P}$ occur in the biofertilizer; and ii) there is a direct correlation between the transformations occurring in the $\mathrm{OM}$ of the manure and those occurring in the organic and inorganic forms of $\mathrm{P}$ during the anaerobic digestion process.

\section{Materials and Methods}

The manure produced by 28 male pigs of the Topigs commercial breed, aged 120 days and weighing approximately $50 \mathrm{~kg}$ each, was used in this study. The manure was collected before the daily washing of the pigs' bays by scraping it off of the floor, yielding $50 \mathrm{~kg}$ of manure with a humidity of about $70 \%$. Manure was conditioned in 21 non-agitated anaerobic bench reactors, made of 150-mm diameter polyvinyl chloride (PVC) pipes with a length of $0.5 \mathrm{~m}$ and a working volume of $8 \mathrm{~L}$ each (Figure 1). The reactors were evaluated at the following hydraulic retention times (HRT): after 7, $14,21,28,35,42$, and 49 days of digestion. Three replicates of each treatment (HRT) were assessed, and raw manure was used as the control treatment, for a total of 24 experimental units.

Figure 1. One of the bench anaerobic reactors used in this study (A) and its respective gasometer (B), coupled together by a silicone hose $(\mathrm{C})$.

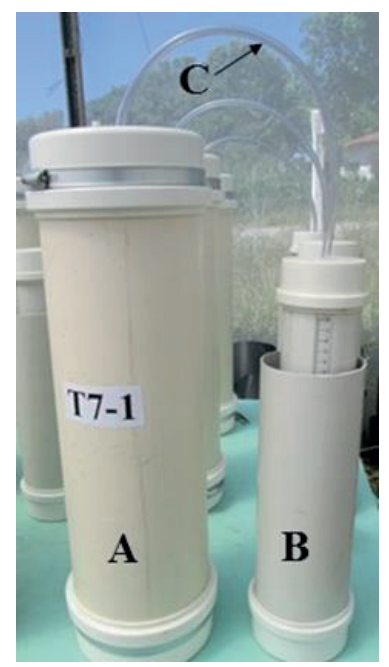

Semina: Ciências Agrárias, Londrina, v. 40, n. 5, suplemento 1, p. 2017-2120, 2019 
At the beginning of the experiment, a portion of the manure collected $(1.3 \mathrm{~kg})$ and water $(6.7 \mathrm{~L})$ was added to all of the reactors to achieve an initial total solids content of 5\%. After filling the reactors, they were sealed to prevent air from entering, and a silicone tube was connected in the center of their upper end to allow the biogas produced to escape. PVC gasometers were coupled to the upper parts of the reactors through silicon tubes that allowed the biogas produced to be stored and measured.

The gasometers consisted of two 100- and 75$\mathrm{mm}$ diameter PVC tubes that were $30 \mathrm{~cm}$ in length, one inserted inside the other so that the space between the outer wall of the inner cylinder and the inner wall of the outer cylinder contained a volume of water (water seal) that reached a depth of $25 \mathrm{~cm}$. The larger diameter tube was closed at its lower end and received the smaller diameter tube inside itself. The smaller diameter tube was closed at its upper end, to which the silicone tube exiting the reactor was coupled and sealed in the water seal to store the biogas (ORRICO JUNIOR et al., 2012).

The volume of biogas produced daily was determined by quantifying the vertical displacement of the gasometers, which was multiplied by the area of the internal cross section of the smaller diameter pipe (i.e. $11.0 \mathrm{~cm}^{2}$ ). After each assessment, the gasometers were emptied by discharging the accumulated biogas, and the internal temperature was measured using a digital infrared thermometer with a laser sight (ScanTemp TS-500).

Each reactor battery (3 replicates) was emptied at its respective $\mathrm{HRT}$, and the $\mathrm{pH}$ was measured directly in the manure with a Consort C860 multiparameter analyzer. An aliquot of the manure was immediately collected for the quantification of the content of inorganic phosphorus $\left(\mathrm{PO}_{4}^{-3}\right.$, using Standard Methods $4500 \mathrm{P}$ and $\mathrm{E}$ ), inorganic nitrogen $\left(\mathrm{NH}_{4}^{+}\right.$, using Standard Methods $4500 \mathrm{~B}$ and C), and total solids (TS, using Standard Method 2540 B) according to APHA Standard Methods (1998). The content of free $\mathrm{NH}_{3}$ was obtained according to equation (1), proposed by Hansen et al. (1998), as follows:

$$
\frac{\left[\mathrm{NH}_{3}\right]}{\left[\mathrm{T}-\mathrm{NH}_{3}\right]}=\left(1+\frac{10^{-p H}}{10^{-\left(0,09018+\frac{2729,92}{T(K)}\right)}}\right)
$$

where $\left[\mathrm{NH}_{3}\right]$ is the concentration of free ammonia $\left(\mathrm{mg} \mathrm{L}^{-1}\right),\left[\mathrm{T}-\mathrm{NH}_{3}\right]$ is the total concentration of ammonia $\left(\mathrm{mg} \mathrm{L}^{-1}\right)$, and $\mathrm{T}(\mathrm{K})$ is the temperature (in degrees Kelvin).

The solid phase of the manure was then separated with the aid of a $1.0-\mathrm{mm}$ mesh sieve. A portion of the solid fraction was placed in a forced circulation oven at $65^{\circ} \mathrm{C}$ until it reached a constant weight, and then passed through a sieve with a $0.5 \mathrm{~mm}$ mesh size to obtain the $\mathrm{P}$ fractions. The content of $\mathrm{C}$ in the humic and oxidizable fractions of $\mathrm{OM}$ was determined in these dried samples.

The total organic carbon (TOC) content was obtained by performing the oxidation of $\mathrm{C}$ with potassium dichromate in acidic medium (YEOMANS; BREMNER, 1988), and the total nitrogen (TN) content was obtained by sulfuric acid digestion (TEDESCO et al., 1995), quantified in a micro-Kjeldahl distiller, and expressed in terms of the weight of the dry residue.

The changes in the OM content and composition throughout the digestion process were quantified through of the amounts of $\mathrm{C}$ that was present in the humic and oxidizable fractions of OM. The humic fractions were extracted and separated according to the procedures described by Sanchez-Monedero et al. (1996), and the C content in each fraction was quantified according to Benites et al. (2003). The organic $\mathrm{C}$ was first extracted in a $0.1 \mathrm{M}$ solution of $\mathrm{NaOH}$ at a ratio of $1 / 20(\mathrm{~m} / \mathrm{v})(\mathrm{C}-\mathrm{Ext})$, and then it was separated into two fractions: fulvic acid fraction carbon (C-FA) and humic acid fraction carbon (CHA).

The alkaline extract, containing the C-Ext, was acidified ( $\mathrm{pH}=1 \pm 0.1)$ with a $20 \% \mathrm{H}_{2} \mathrm{SO}_{4}$ solution, forcing the precipitation of the humic acid fraction 
and separating it from the fulvic acid fraction. The content of the C-Ext and the C-FA fractions was quantified through the oxidation of $\mathrm{C}$ by $0.042 \mathrm{M}$ potassium dichromate in an acidic medium and titration with a $0.0125 \mathrm{M}$ solution of ammonium ferrous sulfate. The size of the C-HA fraction was obtained by calculating the difference between the C-Ext and the C-FA fractions measured.

The oxidizable $\mathrm{C}$ fractions of the manure were obtained following the procedures carried out by Chan et al. (2001), using 2.5, 5.0, and $7.5 \mathrm{~mL}$ of $\mathrm{H}_{2} \mathrm{SO}_{4}$ for the quantification of $\mathrm{C}$, resulting in acid:aqueous ratios $\left(1 \mathrm{~mL}\right.$ of $\mathrm{H}_{2} \mathrm{SO}_{4}: 10 \mathrm{~mL}$ of $\mathrm{K}_{2} \mathrm{Cr}_{2} \mathrm{O}_{7}$ ) of $0.25: 1,0.5: 1$, and $0.7: 1$, respectively, which correspond to final concentrations of 3.6, 6.0 , and $7.7 \mathrm{M}$ of $\mathrm{H}_{2} \mathrm{SO}_{4}$, respectively. The $\mathrm{C}$ content determined in each of the three wet $\mathrm{H}_{2} \mathrm{SO}_{4}$ concentrations (WALKLEY; BLACK, 1934), together with the TOC measurement, enabled four fractions with a decreasing degree of oxidation to be obtained as follows: $\mathrm{F} 1$, the oxidizable $\mathrm{C}$ obtained with 3.6 $\mathrm{M} \mathrm{H}_{2} \mathrm{SO}_{4}$; F2, the difference between the oxidizable $\mathrm{C}$ obtained with 6 and $3.6 \mathrm{M} \mathrm{H}_{2} \mathrm{SO}_{4}$; F3, the difference between the oxidizable $\mathrm{C}$ obtained with 7.7 and $6 \mathrm{M} \mathrm{H}_{2} \mathrm{SO}_{4}$; and $\mathrm{F} 4$, the difference between the TOC and the oxidizable $\mathrm{C}$ obtained with $7.7 \mathrm{M} \mathrm{H}_{2} \mathrm{SO}_{4}$.

The organic $(\mathrm{Po})$ and inorganic (Pi) forms of $\mathrm{P}$ in the manure were obtained according to the methods of Takahashi et al. (2013) as follows: 0.3$\mathrm{g}$ samples of the dry manure were placed in 50 $\mathrm{mL}$ centrifuge tubes, and then the $\mathrm{P}$ in them was extracted sequentially in $30 \mathrm{~mL}$ of distilled water ( $\mathrm{Pi}-\mathrm{H}_{2} \mathrm{O}$ and $\mathrm{Po}-\mathrm{H}_{2} \mathrm{O}$ ), 0.5 M NaHCO${ }_{3}$ (Pi-Bic and Po-Bic), $0.1 \mathrm{M} \mathrm{NaOH}$ (Po-Hid and Pi-Hid), and 1 $\mathrm{M} \mathrm{HCl}$ (Pi-HCl). After homogenization for $16 \mathrm{~h}$ in each extractor, the samples were centrifuged at 5000 rpm for $20 \mathrm{~min}$ to separate the liquid extractor from the remaining solid residue for use in the following extraction.
A $10-\mathrm{mL}$ aliquot of each extract was used separately for the quantification of Pi by colorimetry at $660 \mathrm{~nm}$ (MURPHY; RILEY, 1962), and the remaining $20 \mathrm{~mL}$ were subjected to digestion with $\mathrm{H}_{2} \mathrm{SO}_{4} / \mathrm{H}_{2} \mathrm{O}_{2}$ to obtain the total P (TP) of each extract according to Tedesco et al. (1995). The Po of each extract was obtained as the difference between the total extract $\mathrm{P}$ and the Pi. The residual P (P-Res) was obtained by calculating the difference between the TP of the sample and the sum of the PT content of each extract.

To evaluate the effects of digestion time on the sizes of the humic and oxidizable $\mathrm{C}$ fractions and on the content of the organic and inorganic forms of $\mathrm{P}$, the data were submitted to analysis of variance (ANOVA), adopting an entirely randomized design, with the mean values for each variable at the different HRT compared using Tukey test with a 5\% significance threshold. These analyses were done in the Assistat 7.7 beta statistical program (SILVA; AZEVEDO, 2002). The multivariate principal component analysis (PCA) technique was also used to verify whether a relationship existed between the changes in $\mathrm{OM}$ content and the content of the organic and inorganic forms of $\mathrm{P}$ with digestion time.

\section{Results and Discussion}

The maximum production of biogas occurred between the eighth $(211.0 \mathrm{~mL})$ and the thirteenth day $(197.8 \mathrm{~mL})$ after the beginning of digestion and, therefore, this was presumably the period of greatest microbial activity (Figure 2). From the sixteenth day onward, there was a reduction in the production of biogas, with the minimum production observed on the $37^{\text {th }}$ day, after which no biogas was produced until the end of the experiment. During the 49 experimental days, we observed an accumulated production of $2861.8 \mathrm{~mL}$ of biogas. 
Figure 2. Daily production of biogas $\left(\mathrm{mL} \mathrm{day}^{-1}\right)$ and accumulated production of biogas $(\mathrm{mL})$ during the digestion process.

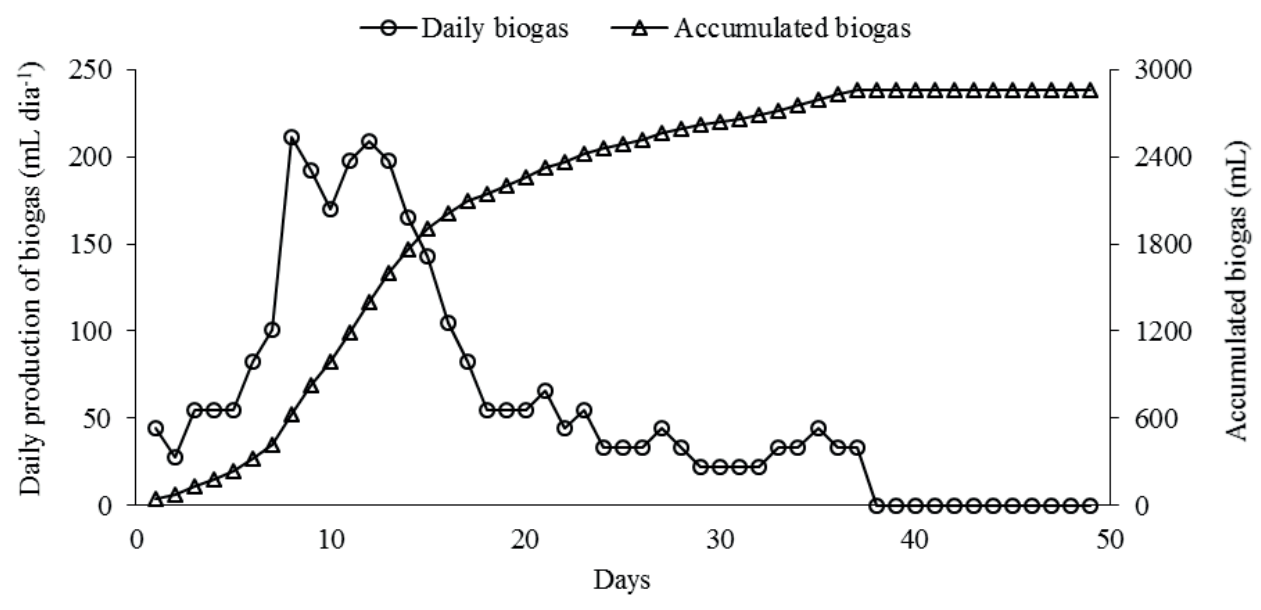

Table 1 presents the $\mathrm{pH}$ values, content of total solids (TS), TOC, total nitrogen (TN), inorganic phosphate $\left(\mathrm{PO}_{4}^{-}\right)$, and the $\mathrm{C} / \mathrm{N}$ ratio in the raw manure and throughout the digestion process. There was an increase in the $\mathrm{pH}$ values with digestion time, with the minimum value observed after 7 days $(\mathrm{pH}=7.1)$ and the maximum observed after 28 days $(\mathrm{pH}=8.2)$. The increase in $\mathrm{pH}$ with digestion time is associated with the formation of ammonium carbonate $\left(\left(\mathrm{NH}_{4}\right)_{2} \mathrm{CO}_{3}\right)$ and the removal of $\mathrm{CO}_{2}$ as a result of the transformation of $\mathrm{CO}_{3}{ }^{2-}$ and $2 \mathrm{H}^{+}$to $\mathrm{CO}_{2}$ and $\mathrm{H}_{2} \mathrm{O}$ (MOLLER; MULLER, 2012). A reduction in the TS of $28 \%$ in relation to the initial content was observed as a result of mass loss during the digestion process.

Table 1. Chemical characterization of swine manure and its total solids content during the anaerobic digestion process.

\begin{tabular}{lllllllll}
\hline \multicolumn{7}{c}{ Days of digestion } \\
\hline & Inicial & 7 & 14 & 21 & 28 & 35 & 42 & 49 \\
\hline $\mathrm{pH}$ & $7.6 \mathrm{~b}$ & $7.1 \mathrm{c}$ & $7.2 \mathrm{bc}$ & $7.5 \mathrm{~b}$ & $8.2 \mathrm{a}$ & $8.0 \mathrm{a}$ & $7.9 \mathrm{ab}$ & $7.5 \mathrm{~b}$ \\
$\mathrm{TS}(\%)$ & $5.0 \mathrm{a}$ & $4.5 \mathrm{a}$ & $4.2 \mathrm{ab}$ & $4.0 \mathrm{~b}$ & $3.6 \mathrm{~b}$ & $3.6 \mathrm{~b}$ & $3.6 \mathrm{~b}$ & $3.6 \mathrm{~b}$ \\
$\mathrm{TOC}(\% \mathrm{DM})$ & $40.8 \mathrm{a}$ & $39 \mathrm{a}$ & $39 \mathrm{a}$ & $38.5 \mathrm{a}$ & $38 \mathrm{a}$ & $38 \mathrm{a}$ & $38 \mathrm{a}$ & $37.7 \mathrm{a}$ \\
$\mathrm{TN}(\% \mathrm{DM})$ & $3.6 \mathrm{a}$ & $2.5 \mathrm{a}$ & $2.5 \mathrm{a}$ & $2.4 \mathrm{~b}$ & $2.3 \mathrm{~b}$ & $2.0 \mathrm{~b}$ & $1.8 \mathrm{~b}$ & $1.9 \mathrm{~b}$ \\
$\mathrm{PO}_{4}^{-3}\left(\mathrm{mg} \mathrm{L}^{-1}\right)$ & $654 \mathrm{a}$ & $570 \mathrm{~b}$ & $565 \mathrm{~b}$ & $551 \mathrm{~b}$ & $567 \mathrm{~b}$ & $559 \mathrm{~b}$ & $577 \mathrm{~b}$ & $577 \mathrm{~b}$ \\
$\mathrm{C} / \mathrm{N} \mathrm{ratio}^{1}$ & $11.3 \mathrm{~b}$ & $15.5 \mathrm{~b}$ & $15.4 \mathrm{~b}$ & $15.6 \mathrm{~b}$ & $16.5 \mathrm{a}$ & $18.6 \mathrm{a}$ & $20.6 \mathrm{a}$ & $19.2 \mathrm{a}$ \\
\hline
\end{tabular}

Means followed by the same letters in different columns did not significantly differ according to Tukey's test at a 5\% significance threshold. MSD = minimum significant difference: $\mathrm{pH}(\mathrm{MSD}=0.5)$, TS $(\mathrm{MSD}=0.5), \mathrm{TOC}(\mathrm{MSD}=5.2), \mathrm{TN}\left(\mathrm{MSD}^{-}=1.1\right), \mathrm{PO}_{4}^{-}$ $(\mathrm{MSD}=32.8)$, and $\mathrm{C} / \mathrm{N}$ ratio $(\mathrm{MSD}=4.1) ; \mathrm{DM}=$ dry matter.

The TOC content of the raw manure was $40.8 \%$, and after 49 days of digestion was reduced to $37.7 \%$. The TN content decreased from 3.6 to $1.9 \%$ in the same period, which resulted in an increase in the $\mathrm{C} / \mathrm{N}$ ratio with digestion time. Similarly, the inorganic $\mathrm{P}$ content $\left(\mathrm{PO}_{4}^{-3}\right)$ decreased with digestion time, from $654 \mathrm{mg} \mathrm{L}^{-1}$ at the beginning of the process to $577 \mathrm{mg} \mathrm{L}^{-1}$ after 49 days of digestion.

The ammoniacal $\mathrm{N}\left(\mathrm{NH}_{4}^{+}\right)$content was found to be $2.7 \mathrm{~g} \mathrm{~L}^{-1}$ at the beginning of the experiment, 
and $1.2 \mathrm{~g} \mathrm{~L}^{-1}$ after 49 days of digestion (Figure 3). Normally, one observes an increase in the $\mathrm{NH}_{4}^{+}$ content during the digestion process due to the reduction of the volume of the manure through the emission of $\mathrm{CH}_{4}$ and $\mathrm{CO}_{2}$ (MARCATO et al., 2008). In the case of the reduced $\mathrm{NH}_{4}^{+}$content observed herein, it is possible that this fraction was lost by volatilization in the form of free $\mathrm{NH}_{3}$ as the $\mathrm{pH}$ increased $\left(\mathrm{NH}_{4}^{+}+\mathrm{OH}^{-} \rightarrow \mathrm{NH}_{3}+\mathrm{H}_{2} \mathrm{O}\right)($ MOLLER; MULLER, 2012). From the $20^{\text {th }}$ to the $30^{\text {th }}$ days after the beginning of digestion, there was a considerable increase in the emission of free $\mathrm{NH}_{3}$, which may have contributed to a reduction in microbial activity and a lower production of biogas during that period, since $\mathrm{NH}_{3}$ is an inhibitor of methanogenic activity (RAJAGOPAL et al., 2013).

Figure 3. Changes in ammoniacal nitrogen $\left(\mathrm{NH}_{4}^{+}\right)$and free ammoniacal nitrogen (Free $\mathrm{NH}_{3}$ ) content during anaerobic digestion. Means followed by the same letters did not significantly differ from one another according to Tukey's test at a 5\% significance threshold. MSD = minimum significant difference: $\mathrm{NH}_{4}^{+}(\mathrm{MSD}=822.12)$ and Free $\mathrm{NH}_{3}(\mathrm{MSD}$ $=5.57$ ).

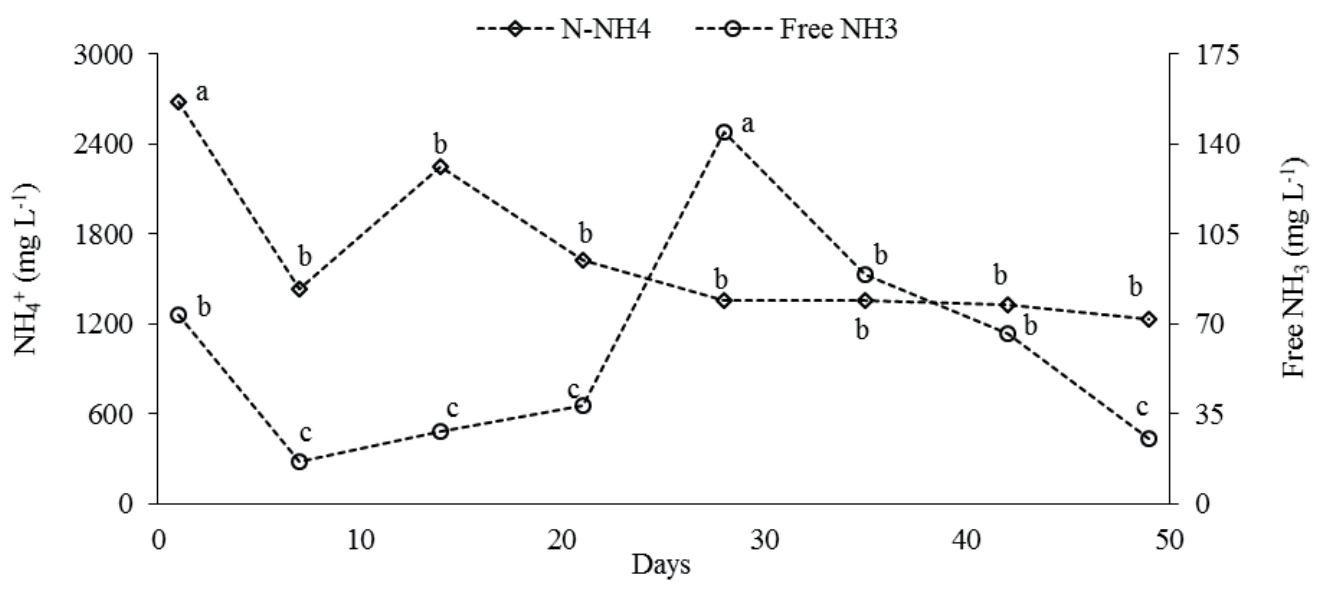

The changes in the OM of the manure obtained through the quantification of the $\mathrm{C}$ content in the humic and oxidizable fractions are presented in Table 2. The C-Ext, obtained with a solution of 0.1 $\mathrm{M} \mathrm{NaOH}$, was $30.6 \%$ of the total $\mathrm{C}$ content in the raw manure, and was reduced to $19.1 \%$ after 49 days of digestion. These low proportions of C-Ext could indicate a low point in the humification of OM due to the stabilization of the manure submitted to AnDi. According to Marcato et al. (2009), the presence of more recalcitrant forms of $\mathrm{C}$ during digestion may be related to the chemical precipitation of carbonates, which is mainly associated with the changes in $\mathrm{Ca}^{2+}$ ions and not to the process of humification of $\mathrm{OM}$ by biological activity, as occurs in the composting of organic waste.
A significant reduction in the C-Ext and the C-FA fractions over the course of the digestion process was observed herein. The C-HA fraction, in turn, showed no significant changes with time. At the beginning of digestion, the C-FA fraction represented a greater proportion of the C-Ext in the manure $(81.2 \%)$ compared to the $\mathrm{C}-\mathrm{AH}$ fraction (18.7\%). However, the size of the C-FA fraction, with its greater lability and thus greater susceptibility to microbial decomposition, was reduced throughout the digestion process, representing $54.6 \%$ of the biodegraded portion of the C-Ext after 49 days, while the C-HA fraction represented $45.3 \%$ of this. 
Table 2. Changes in the content of different organic matter fractions in swine manure during the anaerobic digestion process.

\begin{tabular}{lcccccccc}
\hline \multicolumn{7}{c}{ Days of digestion } \\
\hline & Raw manure & 7 & 14 & 21 & 28 & 35 & 42 & 49 \\
\hline C-Ext & $125.2 \mathrm{a}$ & $78.8 \mathrm{~b}$ & $69.0 \mathrm{c}$ & $87.4 \mathrm{~b}$ & $80.6 \mathrm{~b}$ & $91.5 \mathrm{~b}$ & $67.0 \mathrm{c}$ & $72.4 \mathrm{c}$ \\
$\mathrm{C}-\mathrm{HF}$ & $101.7 \mathrm{a}$ & $60.5 \mathrm{~b}$ & $47.8 \mathrm{c}$ & $65.9 \mathrm{~b}$ & $62.5 \mathrm{~b}$ & $62.0 \mathrm{~b}$ & $37.4 \mathrm{~d}$ & $39.6 \mathrm{~d}$ \\
$\mathrm{C}-\mathrm{AH}$ & $23.5 \mathrm{a}$ & $18.3 \mathrm{~b}$ & $21.2 \mathrm{a}$ & $21.5 \mathrm{a}$ & $18.1 \mathrm{~b}$ & $29.4 \mathrm{a}$ & $29.7 \mathrm{a}$ & $32.8 \mathrm{a}$ \\
& & \multicolumn{7}{c}{ Oxidizable fractions $\left(\mathrm{g} \mathrm{C} \mathrm{kg}{ }^{-1} \mathrm{DM}\right)$} \\
F1 & $81.2 \mathrm{a}$ & $58.7 \mathrm{~b}$ & $42.5 \mathrm{~b}$ & $47.5 \mathrm{~b}$ & $37.5 \mathrm{c}$ & $20.0 \mathrm{~d}$ & $18.6 \mathrm{~d}$ & $12.4 \mathrm{e}$ \\
F2 & $133.7 \mathrm{a}$ & $136.2 \mathrm{a}$ & $107.5 \mathrm{a}$ & $110.0 \mathrm{a}$ & $115.0 \mathrm{a}$ & $130.0 \mathrm{a}$ & $123.8 \mathrm{a}$ & $130.0 \mathrm{a}$ \\
F3 & $126.2 \mathrm{a}$ & $148.7 \mathrm{a}$ & $163.7 \mathrm{a}$ & $176.2 \mathrm{a}$ & $163.7 \mathrm{a}$ & $153.7 \mathrm{a}$ & $171.2 \mathrm{a}$ & $176.2 \mathrm{a}$ \\
F4 & $67.4 \mathrm{a}$ & $46.6 \mathrm{a}$ & $75.1 \mathrm{a}$ & $51.6 \mathrm{a}$ & $64.4 \mathrm{a}$ & $78.0 \mathrm{a}$ & $67.2 \mathrm{a}$ & $59.0 \mathrm{a}$ \\
\hline
\end{tabular}

Means followed by the same letters in different columns did not differ significantly according to Tukey's test at a $5 \%$ significance threshold. MSD = minimum significant difference: C-Ext (MSD = 14.2), C-FA (MSD = 7.2), C-HA (MSD = 12.8), F1 (MSD = $19.5), \mathrm{F} 2(\mathrm{MSD}=41.54), \mathrm{F} 3(\mathrm{MSD}=53.9)$, and F4 $(\mathrm{MSD}=44.8) ; \mathrm{DM}=$ dry matter.

In the case of the oxidizable fractions, a significant reduction in the more labile F1 fraction was observed over the entire biodegradation period. In the raw manure, this fraction represented $19.8 \%$ of the total $\mathrm{C}$ content, while after 49 days it represented only $3.3 \%$ of the total $\mathrm{C}$ content. The sizes of the fractions F2, F3, and F4, being more resistant to degradation, did not change significantly during the digestion process.

As with the C-FA fraction, the changes observed in the F1 fraction seem to illustrate the consumption of easily available OM by microorganisms, which they possibly transformed into $\mathrm{CH}_{4}$ and $\mathrm{CO}_{2}$, and which may have provided an accumulation of more stabilized organic matter over the course of digestion. The C-HA fraction and the F2, F3, and F4 fractions showed similar dynamics to each other, with no changes noted throughout the digestion process.

According to Marcato et al. (2009) and Provenzano et al. (2014), the more labile C fractions consumed during the anaerobic digestion process are those that are possibly associated with lipids, proteins, and carbohydrates, resulting in the accumulation of more resistant and stable $\mathrm{C}$ compounds in the final biofertilizer. This increase in chemical stability can be important during the application of the biofertilizer in agricultural areas as a strategy for the maintenance of organic matter in the soil and reducing the emission of $\mathrm{CO}_{2}$ into the atmosphere.

The total $\mathrm{P}$ content of the manure ranged from 5045 to $4707 \mathrm{mg} \mathrm{P} \mathrm{kg}^{-1}$ in the raw manure and after 49 days of digestion, respectively (Table 3). In general, the total $\mathrm{P}$ values did not vary in statistically significant ways throughout the digestion process, although there was a slight reduction in them of $6.7 \%$ between that in the raw manure and that in the biofertilizer after 49 days of digestion. Unlike $\mathrm{N}$, which may be lost in substantial amounts in the form of $\mathrm{NH}_{3}$ gas depending on the $\mathrm{pH}$ of the medium (RAJAGOPAL et al., 2013), P tends to accumulate, and as a result it was present at high concentrations in the biofertilizer. There is thus the need for methods to estimate the availability of $\mathrm{P}$ in waste to be developed to provide guidance for the application of biofertilizer in agricultural areas, and thereby reduces the risks of environmental contamination. 
Marcato et al. (2008) and Massé et al. (2007) reported a reduction in the total $\mathrm{P}$ content in manures after anaerobic digestion. These authors attributed this reduction to the precipitation of part of the $\mathrm{P}$ content of the manures inside the reactors along with other cations, notably $\mathrm{Ca}^{2+}, \mathrm{Mg}^{2+}, \mathrm{Fe}^{2+}$, and $\mathrm{NH}_{4}^{+}$depending on the $\mathrm{pH}$ of the medium.
However, more detailed studies are required that evaluate the various compartments of this nutrient in the manure given that if part of the P precipitates along with metallic cations during the anaerobic digestion process, this must be considered as part of the biofertilizer, and thus as a portion of the $\mathrm{P}$ extracted with $1 \mathrm{M} \mathrm{HCl}$.

Table 3. Changes in the content of different inorganic and organic forms of $P$ in swine manure during the anaerobic digestion process.

\begin{tabular}{|c|c|c|c|c|c|c|c|c|}
\hline \multirow[b]{2}{*}{ Formas de $\mathrm{P}$} & \multicolumn{8}{|c|}{ Days of digestion } \\
\hline & Raw manure & 7 & 14 & 21 & 28 & 35 & 42 & 49 \\
\hline & \multicolumn{8}{|c|}{ Inorganic $\left(\mathrm{mg} \mathrm{P} \mathrm{kg}^{-1} \mathrm{DM}\right)$} \\
\hline $\mathrm{Pi}-\mathrm{H}_{2} \mathrm{O}$ & $2782 \mathrm{a}$ & $2580 \mathrm{a}$ & $2785 \mathrm{a}$ & $2520 \mathrm{a}$ & $2457 \mathrm{ab}$ & $2276 b$ & $2323 \mathrm{~b}$ & $2316 b$ \\
\hline Pi-Bic & $113 \mathrm{ab}$ & $178 \mathrm{ab}$ & $150 \mathrm{ab}$ & $172 \mathrm{ab}$ & $129 \mathrm{~b}$ & 199 a & $210 \mathrm{a}$ & $197 \mathrm{a}$ \\
\hline Pi-Hid & $2 \mathrm{a}$ & $1 \mathrm{a}$ & $1 \mathrm{a}$ & $1 \mathrm{a}$ & $1 \mathrm{a}$ & $1 \mathrm{a}$ & $1 \mathrm{a}$ & $1 \mathrm{a}$ \\
\hline $\mathrm{Pi}-\mathrm{HCl}$ & $517 \mathrm{a}$ & $597 \mathrm{a}$ & $547 \mathrm{a}$ & 507 a & $500 \mathrm{a}$ & $544 \mathrm{a}$ & $593 \mathrm{a}$ & $505 \mathrm{a}$ \\
\hline$\sum \mathrm{Pi}$ & 3414 & 3356 & 3483 & 3200 & 3087 & 3020 & 3127 & 3019 \\
\hline \multirow[t]{2}{*}{$\%$ PT } & 67.6 & 68.4 & 71.6 & 66.2 & 65.2 & 60.7 & 65.6 & 64.1 \\
\hline & \multicolumn{8}{|c|}{ Organic (mg P kg-1 DM) } \\
\hline $\mathrm{Po}-\mathrm{H}_{2} \mathrm{O}$ & $506 \mathrm{a}$ & $580 \mathrm{a}$ & $563 \mathrm{a}$ & $616 \mathrm{a}$ & $652 \mathrm{a}$ & $587 \mathrm{a}$ & $523 \mathrm{a}$ & $502 \mathrm{a}$ \\
\hline Po-Bic & $288 \mathrm{a}$ & $324 \mathrm{a}$ & $217 \mathrm{a}$ & $261 \mathrm{a}$ & $290 \mathrm{a}$ & $230 \mathrm{a}$ & $357 \mathrm{a}$ & $290 \mathrm{a}$ \\
\hline Po-Hid & $198 \mathrm{a}$ & $168 \mathrm{a}$ & $179 \mathrm{a}$ & $137 \mathrm{a}$ & $169 \mathrm{a}$ & $264 \mathrm{a}$ & $254 \mathrm{a}$ & $279 \mathrm{a}$ \\
\hline$\sum \mathrm{Po}$ & 992 & 1072 & 959 & 1014 & 1111 & 1081 & 1134 & 1071 \\
\hline \multirow[t]{2}{*}{$\%$ PT } & 19.6 & 21.8 & 19.7 & 21.0 & 23.4 & 21.7 & 23.8 & 22.7 \\
\hline & \multicolumn{8}{|c|}{$\left(\mathrm{mg} \mathrm{P} \mathrm{kg}{ }^{-1} \mathrm{DM}\right)$} \\
\hline P-Res & $639 \mathrm{a}$ & $473 \mathrm{a}$ & $418 \mathrm{a}$ & $614 \mathrm{a}$ & $530 \mathrm{a}$ & $868 \mathrm{a}$ & $500 \mathrm{a}$ & $617 \mathrm{a}$ \\
\hline & \multicolumn{8}{|c|}{$\left(\mathrm{mg} \mathrm{P} \mathrm{kg}^{-1} \mathrm{DM}\right)$} \\
\hline PT & $5045 \mathrm{a}$ & $4901 \mathrm{a}$ & $4860 \mathrm{a}$ & $4828 \mathrm{a}$ & $4728 \mathrm{a}$ & 4969 a & $4761 \mathrm{a}$ & $4707 \mathrm{a}$ \\
\hline
\end{tabular}

Means followed by the same letters in different columns did not differ significantly according to Tukey's test at a 5\% significance threshold. $\mathrm{MSD}=$ minimum significant difference: $\mathrm{Pi}-\mathrm{H}_{2} \mathrm{O}(\mathrm{MSD}=334.1)$, Pi-Bic $(\mathrm{MSD}=49.9)$, Pi-Hid $(\mathrm{MSD}=1.6)$, Pi-HCl $(\mathrm{MSD}=131), \mathrm{Po}-\mathrm{H}_{2} \mathrm{O}(\mathrm{MSD}=428.4)$, Po-Bic $(\mathrm{MSD}=293.2)$, Po-Hid $(\mathrm{MSD}=175.6), \mathrm{P}-\mathrm{Res}(\mathrm{MSD}=559)$, and PT $(\mathrm{MSD}=$ 904.2); DM = dry matter.

Inorganic $\mathrm{P}$ represented the largest proportion of the $P$ content of the manure during digestion, ranging between 60.7 and $71.6 \%$ of it. On the other hand, the organic fraction represented between 19.6 and $23.8 \%$ of the total content of this nutrient. Among the fractions obtained in sequential extraction, the $\mathrm{Pi}-\mathrm{H}_{2} \mathrm{O}$ fraction, which represented the content of readily available $\mathrm{P}$, represented the highest percentage of the total content of the nutrient, with values that ranged from 49.2 to $55.1 \%$ of the total $\mathrm{P}$ content throughout the digestion process. The highest $\mathrm{Pi}-\mathrm{H}_{2} \mathrm{O}$ content was observed in the raw manure (2782 $\mathrm{mg} \mathrm{P} \mathrm{kg}^{-1}$ ), which was followed by a period over which this decreased up to the end of the 49 days of digestion, especially from the $28^{\text {th }}$ day onward. After 49 days, a reduction of $16.7 \%$ in the $\mathrm{Pi}-\mathrm{H}_{2} \mathrm{O}$ content was observed, which could contribute to a reduction in the potential 
environmental impacts associated with the use of biofertilizer in agriculture. However, the fact that this fraction represents approximately $50 \%$ of the total content of $\mathrm{P}$ in the final biofertilizer should be viewed with caution, and actions should be carried out to avoid the excessive addition of readily available forms of $\mathrm{P}$ to the soil.

The high content of the more labile fractions of $\mathrm{P}$ is a common characteristic of pig manure. For example, Li et al. (2014) observed that approximately $22 \%$ of the total $\mathrm{P}$ content in pig manure was composed of $\mathrm{Pi}-\mathrm{H}_{2} \mathrm{O}$. According to Tiecher et al. (2014), the $\mathrm{P}$ content in pig manure is accumulated predominantly as inorganic forms of $\mathrm{P}$ with high bioavailability (orthophosphates), representing $99.1 \%$ of the total content of this nutrient. In these cases, anaerobic digestion can be used to reduce the potential environmental contamination due to excess $\mathrm{P}$ in the manure.

According to Gungor and Karthikeyan (2008), the readily available fractions of water-extractable $\mathrm{P}$ are reduced during the anaerobic digestion process, with the subsequent increase in the sizes of more stable fractions due to the decomposition of organic constituents capable of inhibiting the formation of solid stable compounds of $\mathrm{P}$. This could explain the increased $\mathrm{P}$ content in the Pi-Bic fraction observed from the $35^{\text {th }}$ day of digestion onward in this study. The Pi-Bic fraction is the least bioavailable fraction of $\mathrm{Pi}-\mathrm{H}_{2} \mathrm{O}$, and presented values that ranged from 113 to $210 \mathrm{mg} \mathrm{P} \mathrm{kg}^{-1}$ during digestion in this study, representing between 2.2 and $4.1 \%$ of the total $\mathrm{P}$ content, respectively. In this case, there was an increase of $74 \%$ in the size of this fraction after 49 days of digestion. The Pi-Hid fraction, in turn, was more recalcitrant than the Pi-Bic fraction, with insignificant levels of it measured throughout the experimental period.

The $\mathrm{Pi}-\mathrm{HCl}$ fraction displayed values that ranged from 500 to $597 \mathrm{mg} \mathrm{P} \mathrm{kg}^{-1}$ after 28 and 7 days of digestion, respectively, representing between 10.5 to $12.1 \%$ of the total content of this nutrient during the digestion process. Takahashi et al. (2013) and Li et al. (2014) also observed high concentrations of the $\mathrm{Pi}-\mathrm{HCl}$ fraction in animal manure, which, according to these authors, is related to these forms of $\mathrm{P}$ being linked to the low-solubility $\mathrm{Ca}^{2+}$ that accumulates during microbial decomposition. The organic fractions $\mathrm{Po}-\mathrm{H}_{2} \mathrm{O}$, Po-Bic, and Po-Hid, and the P-Res fraction, did not display significant changes throughout the digestion process in the present study. The sum of these fractions represented $33 \%$ of the total content of $\mathrm{P}$ in the raw manure and $42.4 \%$ of that after 49 days of digestion. Accordingly, one can infer that modifications in the $\mathrm{P}$ content of the manure during the anaerobic digestion process occurred only to the inorganic fractions of this nutrient.

To understand the relationship between changes in $\mathrm{OM}$ and the organic and inorganic fractions of $\mathrm{P}$ during the anaerobic digestion process, principal component analysis (PCA) was performed using a data matrix consisting of nineteen variables. The Kaiser criterion, which considers only the principal components with eigenvalues larger than the mean value of all the eigenvalues as containing valuable information, was used to reduce the number of factors (FIGUEREDO FILHO; SILVA JUNIOR, 2010). Thus, only principal components 1 and 2 met this criterion. These two components together explained $61.62 \%$ of the total variance in the data, with 40.57 and $21.05 \%$ of the variance explained by principal components 1 and 2, respectively (Figure 4).

Figure 5 clearly reveals the existence of a significant relationship between the measured content of the C-FA and C-Ext fractions of organic matter, $\mathrm{NH}_{4}^{+}$, and $\mathrm{NH}_{3}$. This pattern indicated that increases or decreases in the content of $\mathrm{NH}_{4}^{+}$and $\mathrm{NH}_{3}$ during the anaerobic digestion process are influenced directly by the impacts of microbial activity on the organic matrix of the manure. A positive correlation was also observed between the $\mathrm{F} 1$ fraction and the $\mathrm{Pi}-\mathrm{H}_{2} \mathrm{O}$ fraction, which may explain the proposition that the labile fractions of $\mathrm{OM}$, which prevent the formation of stable forms 
of $\mathrm{P}$, are consumed during the anaerobic digestion process, causing more labile forms of $\mathrm{P}$ to become more recalcitrant forms, represented by the Pi-Bic fraction in the present study. Among the P fractions, a negative correlation was observed between the Pi$\mathrm{H}_{2} \mathrm{O}$ and Pi-Bic fractions, and therefore a decrease in the former of these promoted an increase in the latter. After the consumption of the C-FA fraction, the dynamics of $\mathrm{P}$ forms during the anaerobic digestion process assumed a totally inorganic role (dissolution and precipitation), without the participation of organic agents, and most of the organic $\mathrm{P}$ in the manure did not undergo any mineralization during the anaerobic digestion process.

Figure 4. Eigenvalues and variability in the data explained by each principal component according to principal component analysis (PCA).

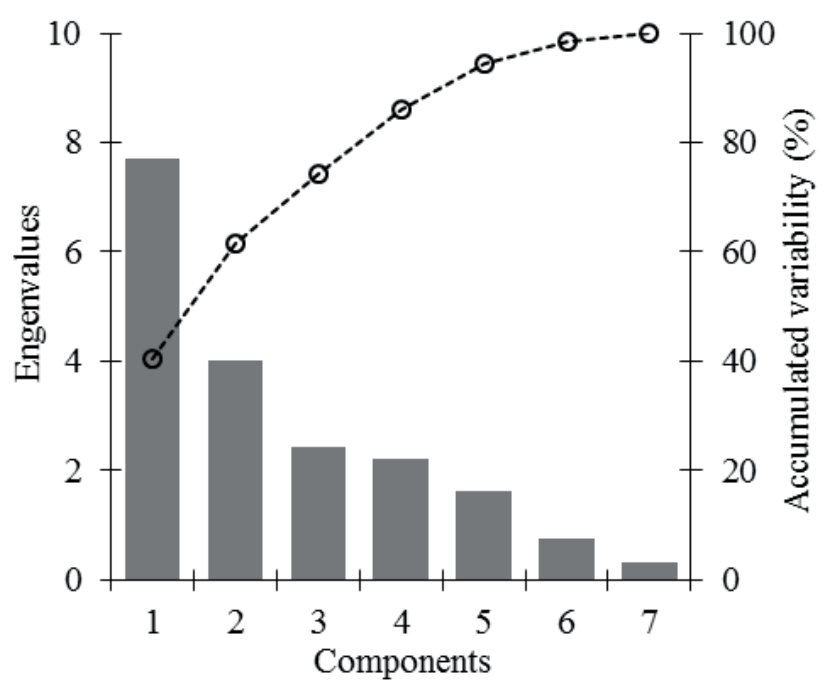

Figure 5. Dispersion of different fractions of organic matter, nitrogen, and the organic and inorganic forms of phosphorus during the anaerobic digestion process.

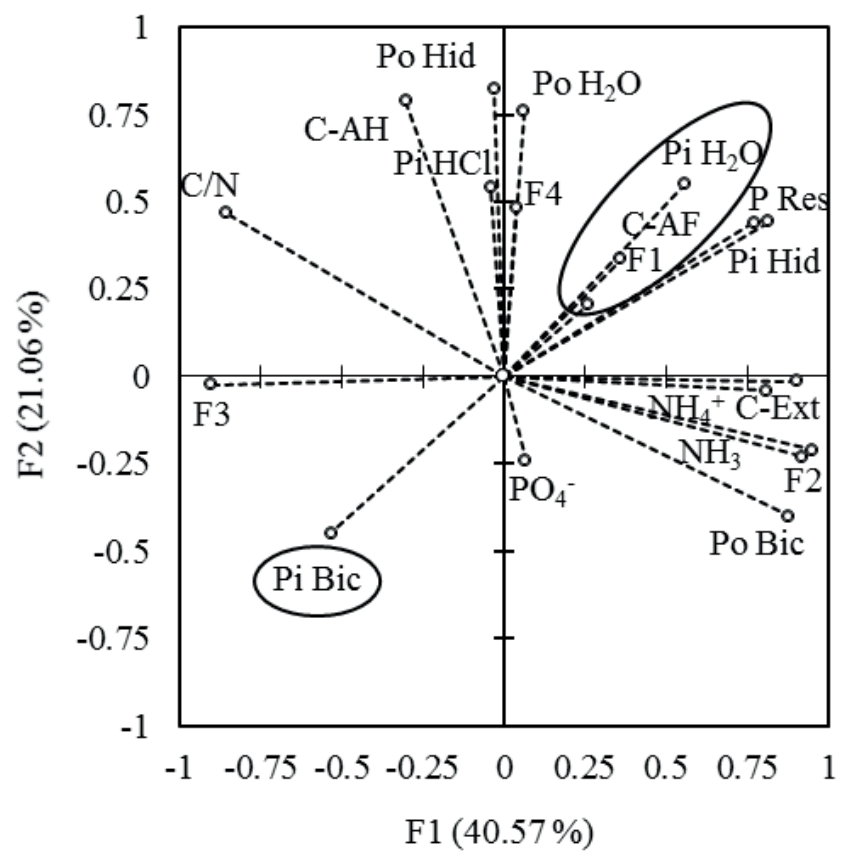




\section{Conclusions}

1. The anaerobic digestion of pig manure stimulated the reduction of the more labile fractions of organic matter and the accumulation of the more recalcitrant fractions in the final biofertilizer.

2. The total P content underwent no changes throughout the digestion process, and the waterextractable inorganic fraction of $\mathrm{P}$ accounted for over $50 \%$ of the total $\mathrm{P}$ content throughout this process.

3. There was a direct relationship between changes in the OM of the manure and changes in the inorganic fractions of $\mathrm{P}$ during the digestion process. The consumption of the C-FA fraction promoted a reduction in the content of more labile forms of $\mathrm{P}$, resulting in the accumulation of more recalcitrant forms during the digestion process.

4. The anaerobic digestion of pig manure can be used as strategy to reduce the content of highly soluble forms of $\mathrm{P}$ in the manure, and therefore reduce the potential for contamination associated with the agricultural use of manure in the soil.

\section{References}

AMERICAN PUBLIC HEALTH ASSOCIATION APHA. Standard methods for the examination of water and wastewater. $19^{\text {th }}$ ed. Washington: American Public Health Association/American Water Works Association/ Water Environment Federation, 1998.

BENITES, V. M.; MADARI, B.; MACHADO, P. L. O. A. Extração e fracionamento quantitativo de substâncias húmicas do solo: um procedimento simplificado de baixo custo. Rio de Janeiro: EMBRAPA Solos, 2003. 7 p. (Comunicado técnico, 16).

CHAN, K. Y.; BOWMAN, A.; OATES, A. Oxidizible organic carbon fractions and soil quality changes in an oxic paleustalf under different pasture leys. Soil Science, Philadelphia, v. 166, n. 1, p. 61-67, 2001. DOI: 10.1097/00010694-200101000-00009

FIGUEREDO FILHO, D. B.; SILVA JUNIOR, J. A. Visão além do alcance: uma introdução a análise fatorial. Opinião Pública, Campinas, v. 16, n. 1, p. 160-185, 2010. DOI: $10.1590 / \mathrm{S} 0104-62762010000100007$
FONGARO, G.; GARCIA-GONZALEZ, M. C.; HERNANDEZ, M.; KUNZ, A.; BARARDI, C. R. M.; RODRIGUEZ-LAZARO, D. Different behavior of enteric bacteria and viruses in clay soils after biofertilization with swine digestate. Frontiers in Microbiology, Lausanne, v. 8, n. 74, p. 1-9, 2017. DOI: 10.3389/fmicb.2017.00074

GARCIA-ALBACETE, M.; MARTIN, A.; CARTAGENA, C. Fractionation of phosphorus biowastes: Characterization and environmental risk. Waste Management, New York, v. 32, n. 6, p. 1061-1068, 2012. DOI: $10.1016 /$ j.wasman.2012.02.003

GUNGOR, K.; KARTHIKEYAN, K. G. Phosphorus forms and extractability in dairy manure: a case study for Wisconsin on-farm anaerobic digesters. Bioresourse Technology, New York, v. 99, n. 2, p. 425-436, 2008. DOI: 10.1016/j.biortech.2006.11.049

HANSEN, K. H.; ALGELIDAKI, I.; AHRING, B. K. Anaerobic digestion of swine manure: inhibition by ammonia, Water Research, London, v. 32, n. 1, p. 5-12, 1998. DOI: 10.1016/S0043-1354(97)00201-7

LI, G.; LI, H.; LEFFELAAR, P. A.; SHEN, J.; ZHANG, F. Characterization of phosphorus in animal manures collected from three (dairy, swine, and broiler) farms in China. Plos One, California, v. 9, n. 7, p. 1-8, 2014. DOI: 10.1371/journal.pone.0102698

MARCATO, C. E.; MOHTAR, R.; REVEL, J. C.; POUECH, P.; HAFIDI, M.; GUIRESSE, M. Impact of anaerobic digestion on organic matter quality in pig slurry. International Biodeterioration and Biodegradation, London, v. 63, n. 7, p. 260-266, 2009. DOI: $10.1016 /$ j. ibiod.2008.10.001

MARCATO, C. E.; PINELLI, E.; POUECH, P.; WINTERTON, P.; GUIRESSE, M. Particle size and metal distributions in anaerobilically digested pig slurry. Bioresourse Technology, New York, v. 99, n. 7, p. 23402348, 2008. DOI: 10.1016/j.biortech.2007.05.013

MASSÉ, D. I.; CROTEAU, F.; MASSE, L. The fate of crop nutrients during digestion of swine manure in psychrophilic anaerobic sequencing batch reactors. Bioresource Technology, New York, v. 98, n. 15, p. 28192823, 2007. DOI: 10.1016/j.biortech.2006.07.040

MOLLER, K.; MULLER, T. Effects of anaerobic digestion on digestate nutrient availability and crop growth: a review. Engineering in Life Science, Amsterdam, v. 12, n. 3, p. 242-257, 2012. DOI: $10.1002 /$ elsc. 201100085

MURPHY, J.; RILEY, J. P. A modified single solution method for the determination of phosphate in natural waters. Analytica Chimica Acta, New York, v. 27, n. 1, p. $31-36,1962$. DOI: $10.1016 / \mathrm{S} 0003-2670(00) 88444-5$ 
ORRICO JUNIOR, M. A. P.; ORRICO, A. C. A.; LUCAS JUNIOR, J.; SAMPAIO, A. A. M.; FERNANDES, A. R. M.; OLIVEIRA, E. A. Biodigestão anaeróbia dos dejetos da bovinocultura de corte: influência do período, do genótipo e da dieta. Revista Brasileira de Zootecnia, Viçosa, MG, v. 41, n. 6, p. 1533-1538, 2012. DOI: 10.1590/S1516-35982012000600030

PHILIPPE, F. X.; NICKS, B. Review on greenhouse gas emissions from pig houses: production of carbon dioxide, methane and nitrous oxide by animals and manure. Agriculture, Ecosystems and Environment, Amsterdam, v. 199, n. 2, p. 10-25, 2015. DOI: $10.1016 /$ j. agee.2014.08.015

PROVENZANO, M. R.; MALERBA, A. D.; PEZZOLLA, D.; GIGLIOTTI, G. Chemical and spectroscopic characterization of organic matter during the anaerobic digestion and successive composting of pig slurry. Waste Management, New York, v. 34, n. 7, p. 653660, 2014. DOI: 10.1016/j.wasman.2013.12.001

RAJAGOPAL, R.; MASSE, D. I.; SINGH, G. A critical review on inhibition of anaerobic digestion process by excess ammonia. Bioresource Technology, New York, v. 143, n. 1, p. 632-641, 2013. DOI: 10.1016/j. biortech.2013.06.030

RODRIGUEZ-NAVAS, C.; BJORKLUND, E.; HALLING-SORENSEN, B.; HANSEN, M. Biogas final digestive byproduct applied to croplands as fertilizer contains high levels of steroid hormones. Environmental Pollution, London, v. 180, n. 48, p. 368-371, 2013. DOI: 10.1016/j.envpol.2013.05.011

SANCHEZ-MONEDERO, M. A.; ROIG, A.; MARTINEZ-PARDO, C.; CEGARRA, J.; PAREDES, C. A microanalysis method for determining total organic carbon in extracts of humic substances. Relationships between total organic carbon and oxidable carbon. Bioresource Technology, New York, v. 57, n. 3, p. 291295, 1996. DOI: 10.1016/S0960-8524(96)00078-8

SILVA, F. A. S.; AZEVEDO, C. A. V. Versão do programa computacional Assistat para o sistema operacional Windows. Revista Brasileira de Produtos Agroindustriais, Campina Grande, v. 4, n. 1, p. 71-78, 2002.

SONG, K.; XUE, Y.; ZHENG, X.; LV, W.; QIAO, H.; QIN, Q.; YANG, J. Effects of the continuous use of organic manure and chemical fertilizer on soil inorganic phosphorus fractions in calcareous soil. Scientific Reports, New York, v. 1164, n. 7, p. 1-9, 2017. DOI: 10.1038/s41598-017-01232-2
SZOGI, A. A.; VANOTTI, M. A.; RO, K. S. Methods for treatment of animal manures to reduce nutrient Pollution prior to soil application. Current Pollution Reports, London, v. 1, n. 1, p. 47-56, 2015. DOI: 10.1007/s40726015-0005-1

TAKAHASHI, S. Phosphorus characterization of manure composts and combined organic fertilizers by a sequential-fractionation method. Journal of Soil Science and Plant Nutrition, Temocu, v. 176, n. 1, p. 494-496, 2013. DOI: $10.1002 /$ jpln.201200169

TAMBONE, F.; ADANI, F.; GIGLIOTTI, G.; VOLPE, D.; FABBRI, C.; PROVENZANO, M. R. Organic matter characterization during the anaerobic digestion of different biomass by means of CPMAS ${ }^{13} \mathrm{C}$ NMR spectroscopy. Biomass and Bioenergy, Virginia, v. 48, n. 13, p. 111120, 2013. DOI: $10.1016 /$ j.biombioe.2012.11.006

TEDESCO, J. M.; GIANELLO, C.; BISSANI, C. A.; BOHNEN, H.; VOLKWEISS, S. J. Análises de solo, plantas e outros materiais. 2. ed. Porto Alegre: UFRGS, 1995. 174 p. (Boletim técnico, 5).

TIECHER, T.; ZAFAR, M.; MALLMANN, F. J. K.; BORTOLUZZI, E. C.; BENDER, M. A.; CIOTTI, L. H.; SANTOS, D. R. Animal manure phosphorus characterization by sequential chemical fractionation, release kinetics and ${ }^{31} \mathrm{P}-\mathrm{NMR}$ analysis. Revista Brasileira de Ciência do Solo, Viçosa, MG, v. 38, n. 5, p. 15061514, 2014. DOI: 10.1590/S0100-06832014000500016

TORRI, S. I.; CORREA, R. S.; RENELLA, G. Biosolid application to agricultural land - a contribution to global phosphorus recycle: a review. Pedosphere, Beijing, v. 27, n. 1, p. 1-16, 2017. DOI: 10.1016/S1002-0160(15)601060

WALKLEY, A.; BLACK, A. An examination of the degtjareff method for determining soil organic matter and a proposed modification of the chromic acid titration method. Soil Science, New York, v. 37, n. 1, p. 29-38, 1934. DOI: 10.1097/00010694-193401000-00003

YEOMANS, J. C.; BREMNER, J. M. A rapid and precise method for routine determination of organic carbonic in soil. Comunicata Soil Science Plant Analisys, New York, v. 19, n. 13, p. 1476-1476, 1988. DOI: $10.1080 / 00103628809368027$ 
